\title{
Viral susceptibility of newly established cell lines from the Hawaiian monk seal Monachus schauinslandi
}

\author{
Yuanan Lu ${ }^{1, *}$, A. Alonso Aguirre ${ }^{2}$, Yun Wang ${ }^{1}$, Lingbing Zeng ${ }^{1}$, Philip C. Loh ${ }^{1}$, \\ Richard Yanagihara ${ }^{1}$
}

\begin{abstract}
${ }^{1}$ Retrovirology Research laboratory, Pacific Biomedical Research Center, University of Hawaii at Manoa, Leahi Hospital 3675 Kilauea Avenue, Honolulu, Hawaii 96816, USA

${ }^{2}$ Wildlife Trust, Palisades, New York 10913, USA
\end{abstract}

\begin{abstract}
Ten of 11 cell lines, recently established from the snout (MS-SN), periorbital soft tissue (MS-EY), liver (MS-LV), kidney (MS-KD), lung (MS-LG), spleen (MS-SP), heart (MS-HT), thyroid (MS-TY), brain (MS-BR) and urinary bladder (MS-UB) of a juvenile Hawaiian monk seal Monachus schauinslandi, were evaluated in vitro for their susceptibility to 5 mammalian viruses: herpes simplex virus type 1 (HSV-1), vesicular stomatitis virus (VSV), reovirus type 3 (Reo-3), poliovirus type 1 (Polio1) and vaccinia virus (Vac); 5 fish viruses: channel catfish herpesvirus (CCV), infectious hematopoietic necrosis virus (IHNV), infectious pancreatic necrosis virus (IPNV), fish rhabdovirus carpio (RC) and viral hemorrhagic septicemia virus (VHSV); and 2 marine mammal morbilliviruses: phocine distemper virus (PDV) and dolphin distemper virus (DMV). Four well-established continuous cell-lines of nonhuman primate (Vero) and fish (EPC, CHSE-214 and BB) origin served as controls to standardize the virus infectivity assays. Virus yields were quantified as $50 \%$ tissue culture infectious dose $\left(\mathrm{TCID}_{50}\right) \mathrm{ml}^{-1}$ on Day 7 post-inoculation. Results of the viral challenge assays revealed that the monk seal cell lines shared a similar pattern of susceptibility to the mammalian viruses. Despite their different tissue origins, all monk seal cells were sensitive to HSV-1, Vac, VSV and Reo-3, but were refractory to Polio-1. A characteristic viral-induced cytopathic effect was noted with VSV and Reo-3, and distinct plaques were observed for HSV-1 and Vac. Monk seal cell lines were also susceptible to PDV and DMV, 2 morbilliviruses isolated from seals and dolphins, respectively. By contrast, these cell lines were generally resistant to VHSV, IHNV and IPNV, with varying susceptibility to RC and CCV. The wide range of viral susceptibility of these monk seal cell lines suggests their potential value in studying viruses of monk seals and other marine mammals.
\end{abstract}

KEY WORDS: Hawaiian monk seal cell lines · Monachus schauinslandi $\cdot$ Viral susceptibility

\section{INTRODUCTION}

Viruses are among the most common biological agents in the ocean. They infect virtually all organisms in the sea, including seals and other endangered marine species (Fuhrman 1999). Viral infections of pinnipeds have been frequently recorded in the literature, and several viruses, including herpesvirus, calicivirus, Influenza A (H7N7) virus, picornavirus and morbil- livirus, have been reported to cause diseases in this marine group (Smith \& Skilling 1979, Geraci et al. 1982, Osterhaus \& Vedder 1988, Banish \& Gilmartin 1992, Mahy 1993, Gulland et al. 1997). Among these viruses, morbilliviruses constitute a major threat to the health and survival of endangered seals. Since the initial report of morbillivirus infection in seals in 1988 (Osterhaus \& Vedder 1988), these viruses have been increasingly recognized and held responsible for mas- 
sive mortalities of several species of marine mammals (Cook 1989, Barrett et al. 1992, Visser et al. 1993a,b, Hall 1995, Osterhaus et al. 1997, van de Bildt et al. 2000, 2001). Epizootics of morbillivirus infection killed several thousand Baikal seals Phoca siberica in Siberia in 1987/88 (Kennedy 1990, 1998), caused more than 17000 deaths of European harbor seals $P$. vitulina in the North and Baltic Seas in 1988 (Osterhaus \& Vedder 1988), and also thousands of deaths of grey seals Halichoerus grypus in Europe during the late 1980s (Mahy 1993). A recent report has validated the association of morbillivirus infection with a serious outbreak of disease causing mass mortality of Mediterranean monk seals Monachus monachus (Osterhaus et al. 1997, 1998, Harwood 1998).

In spite of the identification of many disease-causing viruses in seals, their study has been very limited. Except for the isolation of a morbillivirus from seal kidney cell cultures (Liess et al. 1989), all other seal viruses have not been isolated or characterized in vitro. To facilitate the isolation and study of monk seal viruses and other viral diseases, we recently established 11 cell lines from multiple tissues of a juvenile Hawaiian monk seal Monachus schauinslandi (Lu et al. 2000). In this report, we describe the susceptibility of 10 of these cell lines to several mammalian and fish viruses, as well as to 2 morbilliviruses isolated from seals and dolphins.

\section{MATERIALS AND METHODS}

Monk seal cell lines. Ten cell lines, derived from a juvenile Hawaiian monk seal, were employed in this analysis (Table 1). Cells were grown at $37^{\circ} \mathrm{C}$ using RPMI-1640 medium supplemented with $20 \%$ fetal bovine serum (FBS) (HyClone), $100 \mathrm{U} \mathrm{ml}^{-1}$ penicillin, $100 \mu \mathrm{g} \mathrm{ml}^{-1}$ streptomycin, $2.5 \mu \mathrm{g} \mathrm{ml}^{-1}$ amphotericin B, $50 \mu \mathrm{g} \mathrm{ml}^{-1}$ gentamicin, and $2 \mathrm{mM}$ glutamine. Cells were fed every 3 to $4 \mathrm{~d}$ and subcultured every 5 to $7 \mathrm{~d}$ at a 1:2 or 1:3 split ratio.

Other cell lines. For viral propagation, titration and control studies, 4 well-established continuous cell lines were used (Table 1). An African green monkey kidney cell line (Vero) (Barron et al. 1970) was grown at $37^{\circ} \mathrm{C}$ for the 5 mammalian viruses and 2 marine mammal morbilliviruses. BB cells derived from brown bullhead fish (Wolf \& Quimby 1969) were grown at $25^{\circ} \mathrm{C}$ for the channel catfish herpesvirus (CCV), and EPC (epithelioma papulosum cyprini) cells from carp (Fijan et al. 1983) were grown at $22^{\circ} \mathrm{C}$ for the fish rhabdovirus carpio (RC). CHSE-214, a cell line established from the Chinook salmon (Nims et al. 1970), was propagated at $20^{\circ} \mathrm{C}$ for infectious pancreatic necrosis virus (IPNV) and at $16^{\circ} \mathrm{C}$ for both viral hemorrhagic septicemia virus (VHSV) and infectious hematopoietic necrosis virus (IHNV). All of these cells were propagated in minimum essential medium (MEM) supplemented with $10 \%$ FBS and other supplements, as described for the RPMI-1640 medium.

Virus stocks. A total of 12 viruses were tested in this study (Table 2), which includes 5 laboratory-established mammalian viruses: herpes simplex virus type 1 (HSV-1) (Flexner 1928), vesicular stomatitis virus (VSV) (Cotton 1926), reovirus type 3 (Reo-3) (Loh et al. 1970), poliovirus type 1 (Polio-1) (Loh et al. 1979) and vaccinia virus (Vac) (Loh \& Payne 1965); 5 fish viruses: CCV (Wolf \& Darlington 1971), IHNV (Amend et al. 1969),

Table 1. Newly established Hawaiian monk seal cell lines and other established cell lines used in viral susceptibility assays. MS$\mathrm{EY}=$ monk seal periorbital soft tissue; MS-SN = monk seal snout; MS-LV = monk seal liver; MS-LG = monk seal lung; MS-HT = monk seal heart; MS-BR = monk seal brain; MS-TY $=$ monk seal thyroid; $\mathrm{MS}-\mathrm{UB}=$ monk seal urinary bladder; $\mathrm{MS}-\mathrm{KD}=$ monk seal kidney; MS-SP = monk seal spleen; $\mathrm{BB}=$ brown bullhead; $\mathrm{EPC}=$ epithelioma papillosum carprini; $\mathrm{CHSE}-214=$ Chinook salmon embryo

\begin{tabular}{|llll|}
\hline Cell line & Tissue & Species of origin & Source \\
\hline MS-SN & Snout & Monachus schauinslandi & Lu et al. (2000) \\
MS-EY & Periorbital & Monachus schauinslandi & Lu et al. (2000) \\
MS-LV & Liver & Monachus schauinslandi & Lu et al. (2000) \\
MS-KD & Kidney & Monachus schauinslandi & Lu et al. (2000) \\
MS-LG & Lung & Monachus schauinslandi & Lu et al. (2000) \\
MS-SP & Spleen & Monachus schauinslandi & Lu et al. (2000) \\
MS-HT & Heart & Monachus Schauinslandi & Lu et al. (2000) \\
MS-TY & Thyroid & Monachus schauinslandi & Lu et al. (2000) \\
MS-BR & Brain & Monachus schauinslandi & Lu et al. (2000) \\
MS-UB & Urinary bladder & Monachus schauinslandi & Lu et al. (2000) \\
EPC & Papillosum & Cyprinus carpini & Fijan et al. (1983) \\
BB & Caudal trunk & Ictalurus nebulosis & Wolf Quimby (1969) \\
CHSE-214 & Embryo & Oncorpharyngodon tshawytscha & Nims et al. (1970) \\
VERO & Kidney & Cercopithecus aethiops & Barron et al. (1970) \\
\hline
\end{tabular}


RC (Fijan et al. 1971), VHSV (Brunson et al. 1989) and IPNV (Wolf et al. 1960) (from Dr. John L. Fryer, Oregon State University); and 2 marine mammal morbilliviruses: phocine distemper virus (PDV) (Cosby et al. 1988) and dolphin distemper virus (DMV) (Domingo et al. 1990) (from Dr. Louise Cosby, The Queen's University of Belfast). Virus stocks were prepared in the 4 established continuous cell lines as indicated above.

Virus infection. Virus infectivity assays were performed by testing 10 monk seal cell lines along with 4 established cell cultures for their capacity to support the replication of mammalian, fish and marine mam- mal morbilliviruses. Cell monolayers, grown in $25 \mathrm{~cm}^{2}$ tissue culture flasks, were inoculated with virus stocks at a multiplicity of infection (MOI) ranging from 0.01 to 0.1 . Following virus adsorption for $1 \mathrm{~h}$ at the temperature optimal for each virus, unabsorbed virus was removed by washing the cell monolayer twice with RPMI-1640 medium containing no FBS. Cultures were then fed with $5 \mathrm{ml}$ RPMI-1640 medium containing $5 \%$ FBS. Virus-inoculated cultures were incubated at a temperature optimal for the replication of each test virus, and subsequently monitored for virus-specific cytopathic effect (CPE). Cultures were frozen at $-30^{\circ} \mathrm{C}$

Table 2. Summary of viruses used in the study

\begin{tabular}{|c|c|c|c|}
\hline Virus & Abbreviation & Family & Source \\
\hline \multicolumn{4}{|l|}{ Fish viruses } \\
\hline Channel catfish virus & $\mathrm{CCV}$ & Herpesviridae & Wolf \& Darlington (1971) \\
\hline $\begin{array}{l}\text { Infectious hematopoietic } \\
\text { necrosis virus }\end{array}$ & IHNV & Rhabdoviridae & Amend et al. (1969) \\
\hline Rhabdovirus carpio & $\mathrm{RC}$ & Rhabdoviridae & Fijan et al. (1971) \\
\hline $\begin{array}{l}\text { Viral hemorrhagic } \\
\text { septicemia virus }\end{array}$ & VHSV & Rhabdoviridae & Brunson et al. (1989) \\
\hline $\begin{array}{l}\text { Infectious pancreatic } \\
\text { necrosis virus }\end{array}$ & IPNV & Birnaviridae & Wolf et al. (1960) \\
\hline \multicolumn{4}{|l|}{ Mammalian viruses } \\
\hline Vaccinia virus & Vac & Poxviridae & Loh \& Payne (1965) \\
\hline Vesicular stomatitis virus & VSV & Rhabdoviridae & Cotton (1926) \\
\hline Poliovirus type 1 & Polio-1 & Picornaviridae & Loh et al. (1979) \\
\hline Herpes simplex virus type 1 & HSV-1 & Herpesviridae & Flexner (1928) \\
\hline Reovirus type 3 & Reo-3 & Reoviridae & Loh et al. (1970) \\
\hline \multicolumn{4}{|l|}{ Distemper viruses } \\
\hline Phocine distemper virus & PDV & Paramyxoviridae & Cosby et al. (1988) \\
\hline Dolphin distemper virus & DMV & Paramyxoviridae & Domingo et al. (1990) \\
\hline
\end{tabular}

Table 3. Comparison of different monk seal cell lines for their support of the propagation of selected viruses. $\mathrm{TCID}_{50}=50 \%$ tissue culture infective dose; ND = not done. See Tables $1 \& 2$ for cell line and virus abbreviations

\begin{tabular}{|c|c|c|c|c|c|c|c|c|c|c|c|c|}
\hline \multirow[t]{2}{*}{ Cell line } & \multicolumn{12}{|c|}{ Titer $\left(\log _{10} \mathrm{TCID}_{50} \mathrm{ml}^{-1}\right)$} \\
\hline & HSV-1 & Vac & VSV & Reo-3 & Polio-1 & $\mathrm{CCV}$ & SVCV & IPNV & IHNV & VHSV & DMV & PDV \\
\hline MS-SN & 5.0 & 5.7 & 6.3 & 4.3 & 0 & 6.3 & 6.0 & 1.5 & 2.5 & 0 & 4.7 & 4.5 \\
\hline MS-EY & 4.5 & 2.5 & 6.7 & 3.0 & 0 & 2.5 & 3.5 & 1.5 & 2.3 & 0 & 3.7 & 3.5 \\
\hline MS-LV & ND & ND & 7.0 & ND & 0 & ND & ND & ND & 2.0 & 0 & 4.5 & 4.5 \\
\hline MS-KD & 6.0 & 6.0 & 8.3 & ND & 0 & 5.5 & 6.7 & 3.0 & 2.5 & 0 & 4.5 & 4.3 \\
\hline MS-LG & 4.3 & 2.7 & 6.7 & 2.5 & 0 & 1.0 & 4.5 & 2.0 & 1.7 & 0 & 3.5 & 3.0 \\
\hline MS-SP & 5.3 & 4.5 & 7.0 & 4.3 & 0 & 1.5 & 3.5 & 3.0 & 2.5 & 0 & 3.7 & 3.5 \\
\hline MS-HT & 6.0 & 6.7 & 6.3 & 4.3 & 0 & 5.3 & 3.5 & 1.5 & 1.5 & 0 & 3.5 & 3.5 \\
\hline MS-BR & 4.0 & 2.7 & 5.7 & 2.5 & 0 & 3.7 & 4.3 & 0 & 3.0 & 0 & 0 & 0 \\
\hline MS-TY & 4.7 & 2.5 & 7.7 & 2.0 & 0 & ND & ND & ND & ND & ND & 4.0 & 4.0 \\
\hline MS-UB & 4.5 & 4.0 & 6.5 & 3.3 & 0 & 3.7 & 2.5 & 1.7 & 2.0 & 0 & 3.5 & 3.0 \\
\hline VERO & 7.0 & 7.0 & 7.7 & 6.3 & 7.7 & ND & ND & ND & ND & ND & 3.5 & 3.0 \\
\hline EPC & ND & ND & ND & ND & ND & ND & 7.0 & ND & ND & ND & ND & ND \\
\hline $\mathrm{BB}$ & ND & ND & ND & ND & ND & 6.0 & ND & ND & ND & ND & ND & ND \\
\hline CHSE-214 & ND & ND & ND & ND & ND & ND & ND & 5.7 & 5.5 & 5.5 & ND & ND \\
\hline
\end{tabular}


when more than $80 \%$ of cells showed CPE, or at Day 7 if no CPE developed.

Virus titration. To determine the virus yield produced from the monk seal cells, infected cultures were thawed, and serially diluted 10-fold in MEM containing $4 \%$ FBS (MEM-4). Diluted virus was then inoculated onto monolayers of their original host cells grown in 96-well plates at $0.1 \mathrm{ml}$ well ${ }^{-1}$ and 4 wells per dilu-

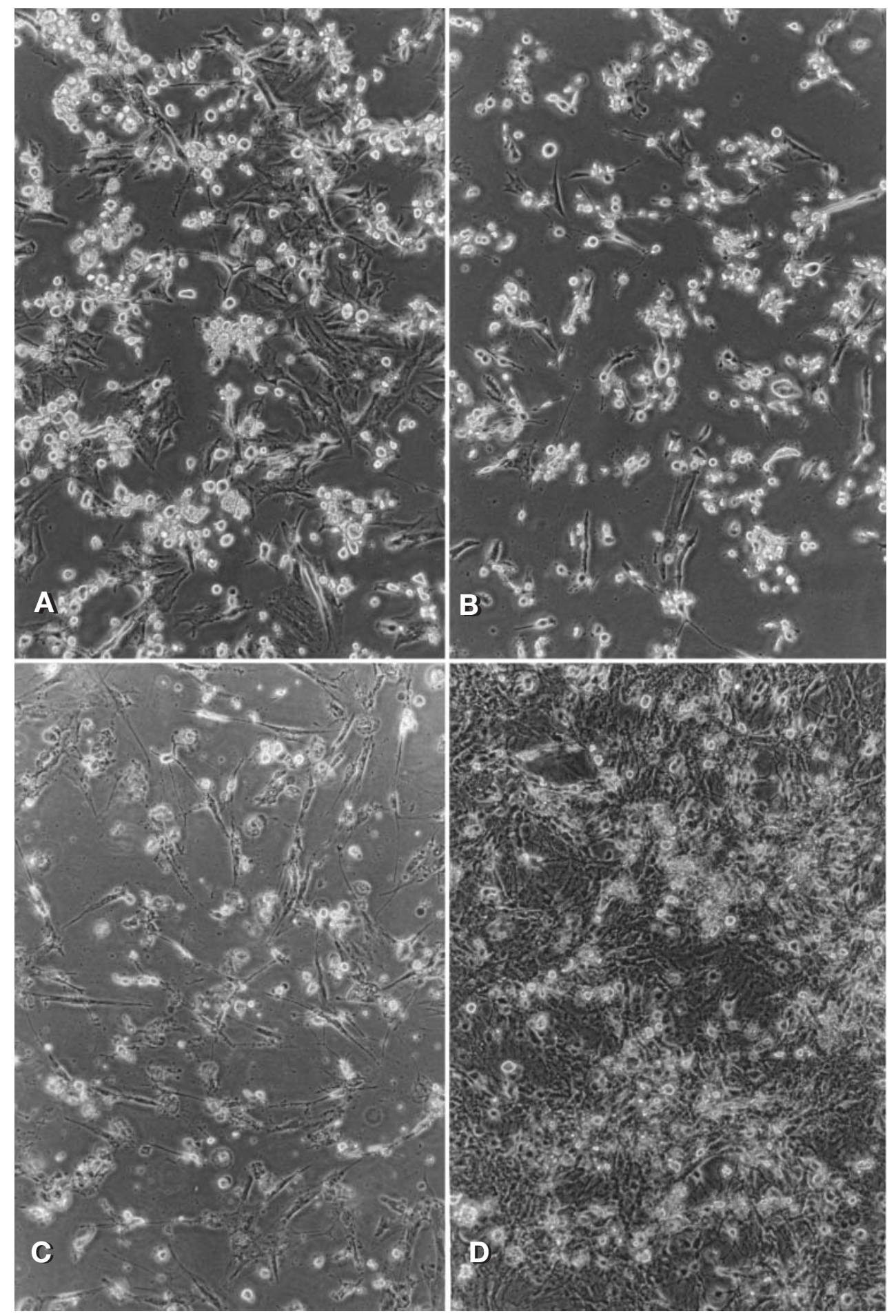

Fig. 1. Phase-contrast microscopic images of cytopathic effect induced by VSV in (A) MS-KD and (B) MS-LG at $24 \mathrm{~h}$ post infection and by Reo-3 in (C) MS-SN and (D) MS-LG at Day 4 
tion. Each plate included 4 negative-control wells inoculated with $0.1 \mathrm{ml} \mathrm{MEM-4}$ well $^{-1}$. Infected plates were covered with plate-sealing Micro test films (Fisher Scientific) and incubated at the temperature optimal for test viruses. Infected cultures were examined every other day for viral-induced CPE and viral titers (50\% tissue culture infectious dose, $\mathrm{TCID}_{50} \mathrm{ml}^{-1}$ ) were determined by the Reed \& Muench (1938) method at Day 7 post-inoculation.

\section{RESULTS}

In vitro challenge of monk seal cell lines was conducted initially with HSV-1, Vac, VSV, Reo-3 and Polio-1. An established Vero cell line was also challenged with these viruses in the same way so as to standardize the virus assays. The results of the viral challenge assays revealed that these monk seal cell lines shared a similar pattern of viral susceptibility. Despite their different tissue origins, all monk seal cell lines were similarly susceptible to VSV (Table 3). VSV propagation in the monk seal cell lines resulted in characteristic viral-induced CPE similar to that observed in VSV-infected Vero cells, including cellrounding, detaching and floating in the medium (Fig. 1). This was observed on Day 2 post-inoculation. VSV yields produced in the monk seal cell lines ranged from $10^{5.7}$ to $10^{8.3} \mathrm{TCID}_{50} \mathrm{ml}^{-1}$, compared to the infectivity titer of $10^{7.7} \mathrm{TCID}_{50} \mathrm{ml}^{-1}$ in Vero cells.

The monk seal cells were also sensitive to HSV-1 and Vac, and viral infection led to the formation of distinct plaques (Fig. 2). The viral-induced plaques began to appear on Day 1 or 2 post-inoculation, and became more distinct, measuring 2 to $3 \mathrm{~mm}$ in diameter following incubation for 2 to 3 additional days. When compared to Vero cells, however, the monk seal cell lines were less efficient in supporting viral propagation, and virus titers ranged from $10^{4.0}$ to $10^{6.0} \mathrm{TCID}_{50} \mathrm{ml}^{-1}$ for HSV-1 and $<10^{2.5}$ to $10^{6.7} \mathrm{TCID}_{50} \mathrm{ml}^{-1}$ for Vac, respectively. Among the new cell lines, MS-HT and MS-KD were found to be the most susceptible to the 2 viruses (Table 3 ).

When compared to VSV, HSV-1 and Vac, Reo-3 induced limited CPE in some of the monk seal cell lines (Fig. 1C,D). Viral infection became visible at Days 5 to 7 post-inoculation, and viral titers in monk seal cell lines were relatively low, ranging from $<10^{2.0}$ to $10^{4.3}$ $\mathrm{TCID}_{50} \mathrm{ml}^{-1}$ (Table 3 ). In contrast, monk seal cell lines were uniformly refractory to Polio-1 (Table 3).

All 10 monk seal cell lines were more resistant to infection with viral strains isolated from cold-blooded animals, specifically VHSV $\left(16^{\circ} \mathrm{C}\right), \operatorname{IHNV}\left(18^{\circ} \mathrm{C}\right)$, and IPNV $\left(20^{\circ} \mathrm{C}\right)$ (Table 3$)$. However, these cell lines showed a diverse pattern of sensitivity to RC and CCV. Among these cell lines, MS-SN and MS-KD exhibited
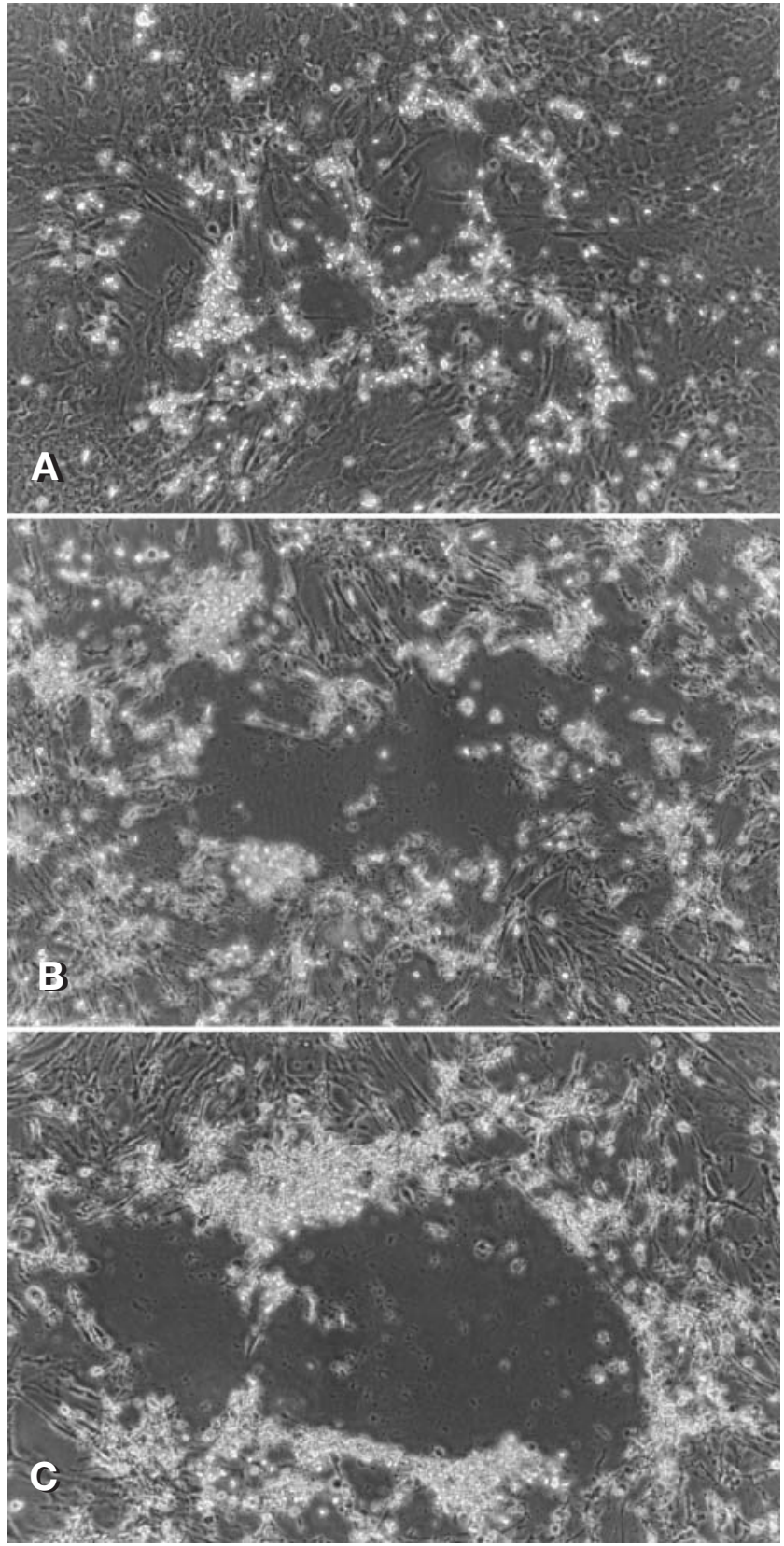

Fig. 2. Plaques induced by HSV-1 in (A) MS-SP and (B) MS$\mathrm{UB}$; and by Vaccinia virus in (C) MS-UB at Day 4 post infection

the greatest sensitivity to these viruses (viral titers: $>10^{5.5} \mathrm{TCID}_{50} \mathrm{ml}^{-1}$ ), followed by MS-HT and MS-BR (viral titers: $10^{3.5}$ to $10^{5.3} \mathrm{TCID}_{50} \mathrm{ml}^{-1}$ ). The remaining cell lines were less sensitive to RC and CCV. Both CCV and $\mathrm{RC}$ replication in MS-SN and MS-KD cells resulted in distinct $\mathrm{CPE}$, and attained viral titers close to those produced in control cells (i.e. CCV in BB cells and RC in EPC cells) (Table 3). As shown in Fig. 3, viral-induced CPE appeared in RC-infected cells (MS$\mathrm{KD})$ at Day 2 post-inoculation and became extensive at 
Day 5 (Fig. 3A). CCV-infected monk-seal skin (MS$\mathrm{SN}$ ) and kidney (MS-KD) cells exhibited viral-specific CPE starting at Day 1 and affecting the entire monolayer by Days 4 or 5 post-inoculation (Fig. 3D).

Challenge of the monk seal cell lines with 2 morbilliviruses revealed a similar pattern of viral susceptibility (Table 3). Propagation of PDV and DMV was observed in all monk seal cell lines except for MS-BR cells, and viral infection in these cultures resulted in viral-specific CPE characterized by the appearance of pycnotic nuclei of affected cells (Fig. 4). When the same inoculum of morbillivirus was added to these cultures, CPE appeared initially in liver-derived cells at Day 2 post-inoculation, suggesting that MS-LV is the most sensitive cell line to these 2 marine mammal viruses. Viral-induced CPE became visible in MS-SN
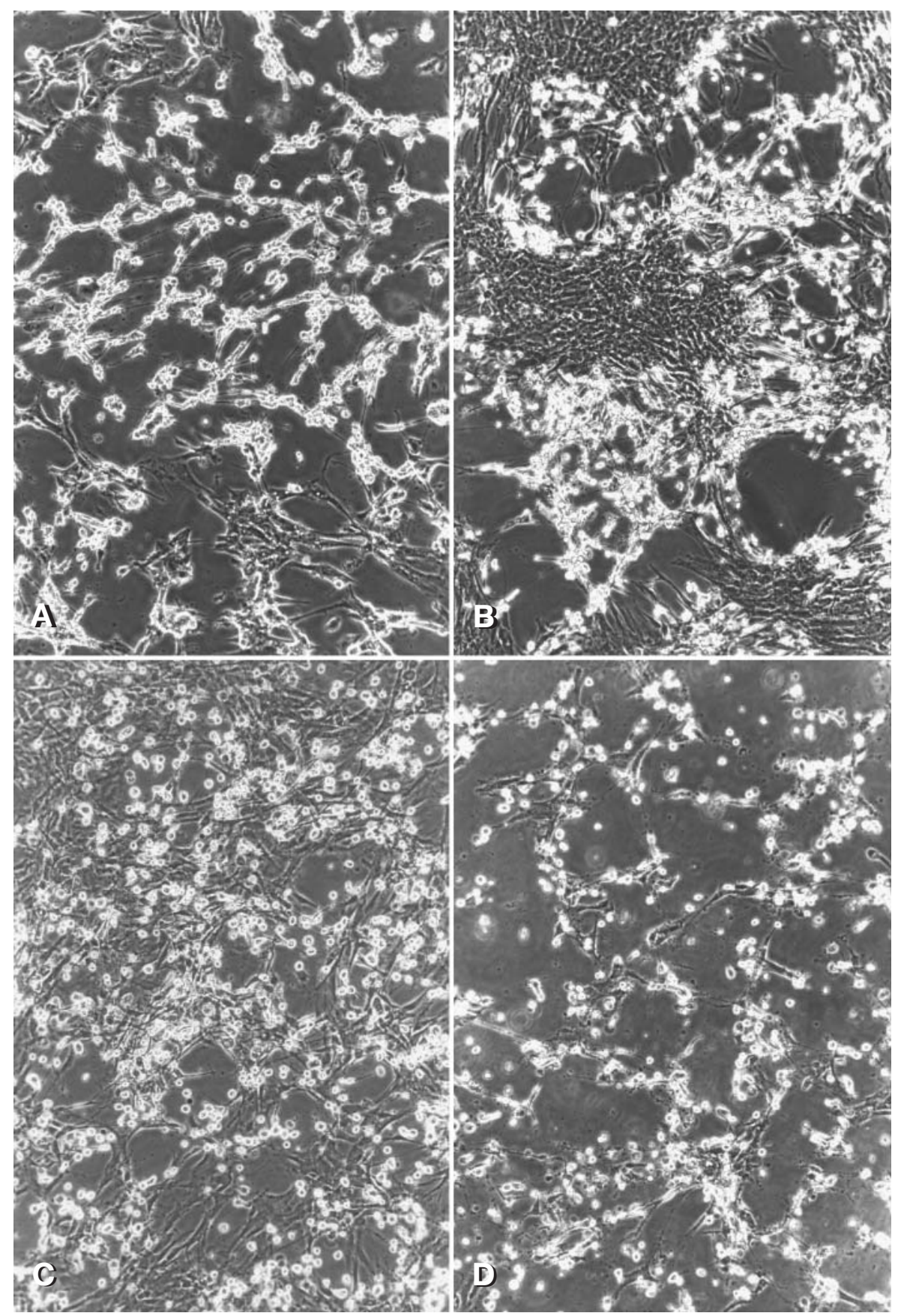

Fig. 3. Photomicrographs of (A) RC-infected MS-KD cells at Day 5, (B) CCV-infected cytopathic effect in MS-KD cells at Day 4, (C) MS-SN cells at Day 2 and (D) Day 5 
cells at Day 3 post-inoculation, MS-KD and MS-LG at Day 4, and at Day 5 or later for the other monk seal cultures. No CPE was observed in MS-BR cells. None of the uninoculated-control monk seal cells showed any $\mathrm{CPE}$, and all remained as intact cell monolayers during the $7 \mathrm{~d}$ observation period (data not shown).

\section{DISCUSSION}

Outbreaks of viral diseases of high mortality in seal populations (Geraci et al. 1982, Osterhaus et al. 1997, Harwood 1998, Fuhrman 1999, van de Bildt et al. 1999, Kennedy et al. 2000) have led us to focus on the devel- opment of cell cultures for the diagnosis and study of latent and virulent seal viruses. We had previously established 11 cell lines from multiple tissues/organs of a juvenile Hawaiian monk seal (Lu et al. 2000), and had proposed that these cell lines would provide a useful tool in the isolation and propagation of viruses infecting Hawaiian monk seals and other marine mammals.

In the present study, we tested and evaluated 10 of these 11 monk seal cell lines for their ability to support the replication of several viruses from mammalian and lower aquatic vertebrate species. Although the new monk seal cell lines shared a similar susceptibility pattern to 5 mammalian viruses, viral replication efficiency among these cell lines varied significantly

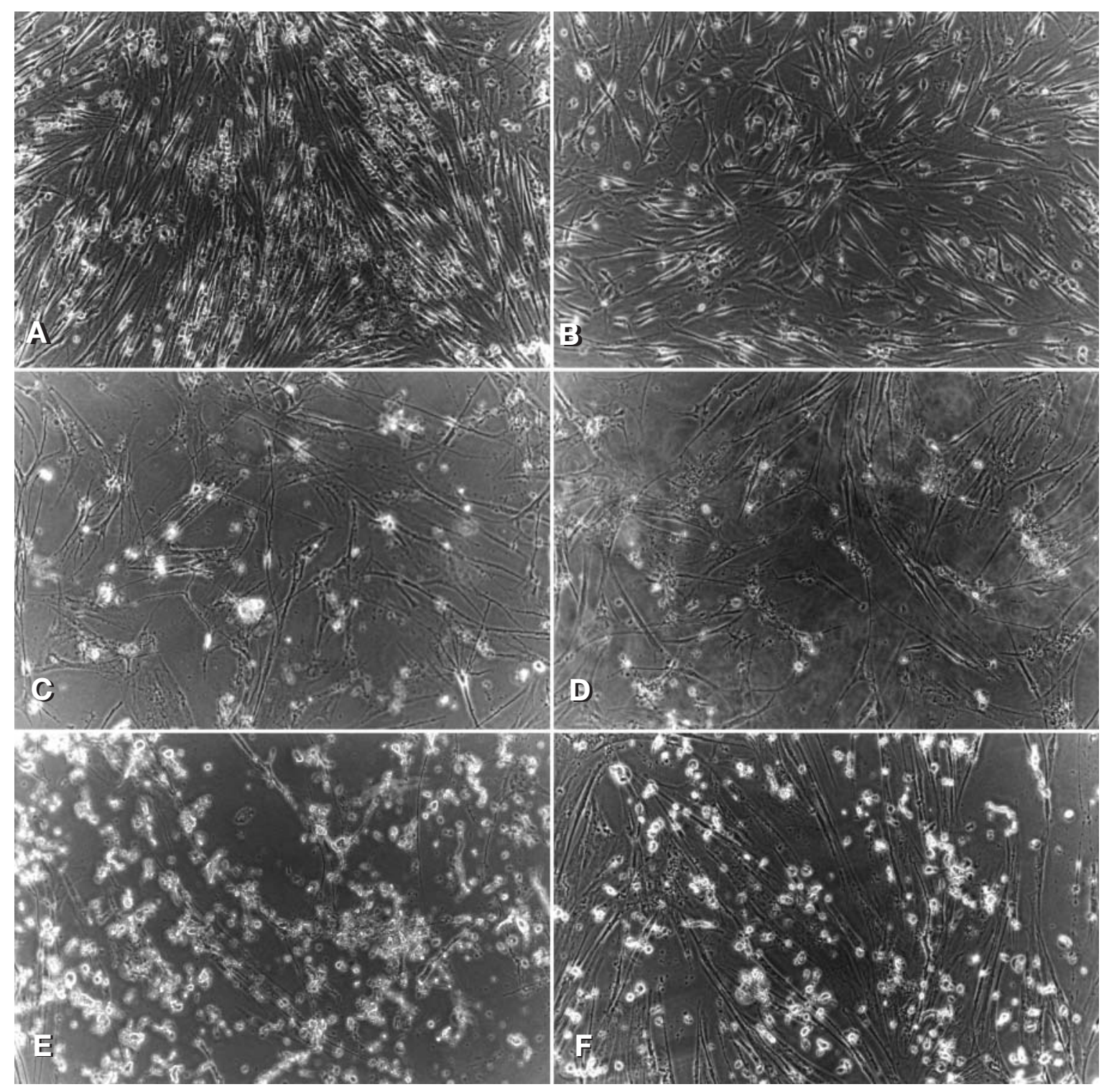

Fig. 4. Photomicrographs of cytopathic effect of Monachus schauinslandi cell lines infected by morbilliviruses. (A) DMV-infected MS-SN, (C) MS-KD and (E) MS-HT, and (B) PDV-infected MS-SN, (D) MS-KD and (F) MS-HT 
depending on the virus type and cell origin. Among the 5 mammalian viruses tested, VSV appeared to be the most effective viral isolate, and could propagate in most monk seal cell lines as efficiently as in the established nonhuman primate Vero cells. In contrast to the high susceptibility to VSV, the monk seal cell lines were much less sensitive to HSV-1, Vac and Reo-3. Although these viruses led to productive viral infection and induced distinctive viral-specific CPE in these cell lines, the viral yields were markedly lower when compared to Vero cells, particularly Reo-3. Since viral production of Reo-3 in these cell lines was inefficient (approximately 100 - to 1000 -fold lower), the viral infection in these cells could easily be overlooked when a low viral inoculum was used $(\mathrm{MOI}<0.01)$ ( $\mathrm{Lu}$ et al. 1998).

Among the 10 monk seal cell lines, MS-KD, MS-SN and MS-HT were found to be the most susceptible to the mammalian viruses examined. The viral titers produced in these cell lines were usually 10- to 1000 -fold higher than those in the other monk seal cells. These preliminary data suggest that these 3 types of monk seal cells should be used preferentially for initial viral isolation and diagnosis.

Evaluation of these 10 newly established monk seal cell lines for their viral sensitivity was based on viral infectivity assays with a $7 \mathrm{~d}$ post-inoculation time, regardless of the incubation temperature. It is notable that this incubation time may not be adequately long for some slowly replicating viruses, particularly those strains isolated from cold-blooded animals. However, the selection of the infection time was grounded on the fact that the viral infections became apparent at Day 7 post-inoculation in all positive control cells, suggesting the establishment of viral infection (which may not be the peak viral production time). In addition, all monk seal cells exhibited very limited or no growth when incubated at $25^{\circ} \mathrm{C}$ or lower temperature. At $16^{\circ} \mathrm{C}$, these monk seal cells could be maintained for a short period of time ( 7 to $10 \mathrm{~d}$ ), and cells appeared to be 'sick' afterwards and began to shrink and detach from the culture flasks. Since all the infected cultures were assayed at the same time, susceptibility of these cell lines to a particular virus could be reasonably compared and determined based on their production of infectious viral progeny.

In contrast to mammalian viruses, the response of each individual monk seal cell line to fish viruses was quite different. For example, MS-BR was quite sensitive to CCV but resistant to IPNV and VHSV, while MS-SP was somewhat susceptible to IPNV but was more resistant to CCV. In general, monk seal cell lines derived from skin (MS-SN) and kidney (MS-KD) appeared to be more sensitive to $\mathrm{CCV}$ and $\mathrm{RC}$ than the other cell lines. Viral yields in these 2 cell lines were
100- to 10000 -fold higher than those generated in the other monk seal cells. Furthermore, it was noted that CCV replicated somewhat more efficiently in MS-SN than it did in BB cells, and that the propagation of VSV in MS-KD was superior to that in Vero cells.

It was not surprising to find that these monk seal cells of non-primate origin were refractory to Polio-1 (Polio-1 LSc2ab) but permissive to CCV and RC from fresh-water fish. Although the monk seal is a marine mammal whose cells grow optimally at $37^{\circ} \mathrm{C}$, our observation substantiated that the cellular properties of the host are more important for viral infection than the optimal temperature for cell culture.

It is of interest to note that some viruses replicate better on particular cell lines than others. Although it is not the focus of this study to illustrate the prospective mechanism of viral tropism, the variation of viral infectivity among the cell lines could be most likely attributed to their different host ranges of test viruses. Some viruses have restricted tropism, and their infection is limited to certain host cells. Enterotropic polioviruses (i.e. Polio-1) represent a very restricted virus strain, and we have demonstrated that this virus causes no infection in any of these monk seal cell lines. In contrast, other viruses can be pantropic and are able to attach to more than one cellular receptor; thus, they can infect and replicate in many cell types. HSV-1 and VSV are pantropic viruses and we have shown that they replicate well in most of the monk seal cell lines. It is known that most viruses do not infect all the cell types of a host, and viral infection requires cells to be both susceptible to the virus and permissive for viral replication (Flint et al. 2000). Failure to support viral infection might not necessarily mean the lack of a cellular receptor for viral entry of a host cell, but could be due to the shortage of differentially expressed intracellular gene products for completion of the infection.

A number of viruses have been reported in marine mammal species (Smith \& Skilling 1979, Cosby et al. 1988, Domingo et al. 1990, Banish \& Gilmartin 1992, Mahy 1993, Birkun 1996, Gulland et al. 1997, Kennedy 1998). We have tested 2 morbilliviruses, PDV and DMV, isolated from seal and dolphin, respectively. All 10 monk seal cell lines that we tested, except for MS$\mathrm{BR}$, were susceptible to these morbilliviruses, and the viral replication in these monk seal cells was observed to be more effective than in Vero cells. Our data suggest that these newly established monk seal cell lines would be a valuable in vitro cell culture system for conducting viral surveillance in marine mammals, particularly monk seals. In addition, the broad range of viral susceptibility to several virus families also attests to the utility of these cell lines for the isolation, propagation and study of viruses infecting other warm- and coldblooded marine species. 
Acknowledgements. We thank Dr. Louise Cosby, Professor of The Queen's University of Belfast, for her assistance and support in the morbillivirus infection study. This research was supported in part by funding from the Wildlife Preservation Trust International, Philadelphia, Pennsylvania, and the Research Centers in Minority Institutions Program, National Center for Research Resources, National Institutes of Health (G12RR003061).

\section{LITERATURE CITED}

Amend DF, Yasutake WT, Mead RW (1969) A hematopoietic virus disease of rainbow trout and sockeye salmon. Trans Am Fish Soc 98:796-804

Banish LD, Gilmartin WG (1992) Pathological findings in the Hawaiian monk seal. J Wildl Dis 28:428-434

Barrett $\mathrm{T}$, Blixenkrone MM, Domingo $\mathrm{M}$, Harder $\mathrm{T}$ and 6 others (1992) Round table on morbilliviruses in marine mammals. Vet Microbiol 33:287-295

Barron AL, Olshevsky C, Cohen MM (1970) Characteristics of the BGM line of cells from African green monkey kidney. Arch Ges Virusforsch 32:389-392

Birkun AA (1996) Viruses of whales and dolphins. Mikrobiol Zool 58:100-106

Brunson RK, True K, Yancey J (1989) VHS virus isolated at Makah National Fisheries Hatchery. Am Fish Soc Fish Health Newsl 17:3

Cook AJ (1989) Morbillivirus infection in seals. Vet Res 125: 465

Cosby SL, McQuaid S, Duffy N, Lyons C and 8 others (1988) Characterization of a seal morbillivirus. Nature 336: 115-116

Cotton WE (1926) Vesicular stomatitis. J Am Med 22:169-176

Domingo M, Ferrier L, Pumarola M, Marco A, Plana J, Kennedy S, McAlisky M, Rima BK (1990) Morbillivirus in dolphins. Nature 348:21

Fijan N, Petrinec Z, Sulimanouie D, Zwillenberg LO (1971) Isolation of the viral causative agent from the acute form of infectious dropsy of carp. Vet Arch 41:125-138

Fijan N, Sulimsnovic D, Bearzotti M (1983) Some properties of the Epithelioma papulosum cyprini (EPC) cell line from carp Cyprinus carpio. Annal Virol 134E:207-220

Flexner S (1928) Contributions to the pathology of experimental virus in encephalitis: recurring strain of herpesvirus. J Exp Med 47:9-22

Flint SJ, Enquist LW, Krug RM, Racaniello VR, Skalka AM (2000) Principles of virology. ASM Press, Washington, DC

Fuhrman JA (1999) Marine viruses and their biogeochemical and ecological effects. Nature 399:541-548

Geraci JR, Aubin DJ, Barker IK, Webster RG and 8 others (1982) Mass mortality of harbor seals: pneumonia associated with influenza A virus. Science 215:129-131

Gulland FM, Lowenstine LJ, Lapointe JM, Spraker T, King DP (1997) Herpesvirus infection in stranded Pacific harbor seals of coastal California. J Wildl Dis 33:450-458

Hall AJ (1995) Morbilliviruses in marine mammals. Trends Microbiol 3:4-9

Harwood J (1998) What killed the monk seals? Nature 393: $17-18$

Kennedy S (1990) A review of the 1988 European seal morbilliviruses epizootic. Vet Res 127:563-567

Kennedy S (1998) Morbillivirus infections in aquatic mammals. J Comp Pathol 119:201-205

Editorial responsibility: Murray Dailey,

Sausalito, California, USA
Kennedy S, Kuiken T, Jepson PD, Deaville R and 9 others (2000) Mass-die off of Caspian seals caused by canine distemper virus. Vet Res 148:210-211

Liess B, Frey HR, Zaghawa A (1989) Morbillivirus in seals: isolation and some growth characteristics in cell cultures. Dtsch Tierarztl Wochenschr 96:180-182

Loh PC, Payne FE (1965) Effect of p-fluorophenylalanine on the synthesis of vaccinia virus. Virology 25:560-572

Loh PC, Oie HK, Ratnayake RMT (1970) Accelerated cytopathology in HeLa cells induced by reovirus and cycloheximide. Infect Immunity 2:705-712

Loh PC, Fujioka RS, Lau LS (1979) Recovery, dissemination and survival of human enteric viruses in the Hawaiian ocean environment. Water Air Soil Pollut 12:197-217

Lu Y, Aguirre AA, Braun RC, Loh PC (1998) Establishment of monk seal cell lines. In Vitro Cell Dev Biol 34:367-369

Lu Y, Aguirre AA, Hamm C, Wang Y, Yu Q, Loh PC, Yanagihara R (2000) Establishment, cryopreservation, and growth of 11 cell lines prepared from a juvenile Hawaiian monk seal, Monachus schauinslandi. Methods Cell Sci 22: $115-124$

Mahy BWJ (1993) Seal plague virus. In: Morse SS (ed) Emerging viruses. Oxford University Press, Oxford, p 185-193

Nims L, Fryer JL, Pilcher KS (1970) Studies of replication of four selected viruses in two cell lines derived from salmonid fish. Proc Soc Exp Biol Med 135:6-12

Osterhaus A, Vedder EJ (1988) Identification of virus causing recent seal deaths. Nature 335:20-22

Osterhaus A, Groen J, Niesters H, van de Bildt BW and 6 others (1997) Morbillivirus in monk seal mass mortality. Nature 388:838-839

Osterhaus A, van de Bildt M, Vedder L, Martina B and 11 others (1998) Monk seal mortality: virus or toxin? Vaccine 16:979-981

Reed LJ, Muench H (1938) A simple method of estimating fifty percent end-points. Am J Hyg 27:493-497

Smith AW, Skilling DE (1979) Viruses and virus diseases of marine mammals. J Am Vet Med Assoc 175:918-920

van de Bildt MW, Vedder EJ, Martina BE, Sidi BA and 6 others (1999) Morbilliviruses in Mediterranean monk seals. Vet Microbiol 69:19-21

van de Bildt MW, Martina BE, Vedder EJ, Androukaki E and 6 others (2000) Identification of morbilliviruses of probable cetacean origin in carcases of Mediterranean monk seals (Monachus monachus). Vet Res 146:691-694

van de Bildt MW, Martina BE, Sidi BA, Osterhaus AD (2001) Morbillivirus infection in a bottlenosed dolphin and a Mediterranean monk seal from the Atlantic coast of West Africa. Vet Res 148:210-211

Visser IK, van Bressem MF, van de Bildt MW, Groen J, Orvell C, Raga JA, Osterhaus AD (1993a) Prevalence of morbilliviruses among pinniped and cetacean species. Rev Sci Technol 12:197-202

Visser IK, van Bressem MF, Barrett T, Osterhaus AD (1993b) Morbillivirus infection in marine mammals. Vet Res 24: $69-78$

Wolf K, Darlington RW (1971) Channel catfish virus: a new herpesvirus of ictalurid fish. J Virol 8:523-533

Wolf K, Quimby MC (1969) Fish cell and tissue culture. In: Hoar WS, Randall DJ (eds) Fish physiology. Academic Press, New York, p 253-305

Wolf K, Snieszko SF, Dunbar CE, Pyle E (1960) Virus nature of infectious pancreatic necrosis in trout. Proc Soc Exp Biol Med 104:105-108

Submitted: June 23, 2003; Accepted: August 5, 2003

Proofs received from author(s): December 12, 2003 